\title{
Planet Earth becomes target for International Space Year
}

\section{Boston}

SPACE agency officials from 16 nations and the European Space Agency (ESA) gathered in Durham, New Hampshire, last week to lay the foundation for a mission to Earth as the chief component of International Space Year (ISY) in 1992. (The International Biosphere-Geosphere Program of the International Council of Scientific Unions is separate, but collaboration is planned.)

1992 will be both the thirty-fifth anniversary of International Geophysical Year and the 500th anniversary of Columbus's voyage to America. Given concern over threats to the Earth's environment, the campaign will pay less attention to neighbouring planets and distant galaxies, but will instead concentrate on a better understanding of the Earth, and how the talents of the world's space agencies can be pooled in a coordinated effort to map global environmental change.

Throughout the three-day conference, representatives stressed links between environmental problems: depletion of the

\section{Australian in space?}

\section{Sydney}

AT talks in Canberra last week, Vyacheslov Dukov, the vice-chairman of the Soviet space agency, offered a flight into space for an Australian cosmonaut. The offer comes amid greatly increased discussion of joint projects in space stimulated by the signing of the US-Soviet Space Research Cooperation Agreement last December.

Bruce Middleton, executive director of the Australian Space Office, believes a manned flight will not happen before the next century. "If at some future date an Australian experiment needed technical expertise, we would consider sending a scientist into space", he said.

The Soviets are particularly interested in using Australia's proposed commercial launch facility in Cape York, North Queensland, for launching Soviet rockets. According to Ken McCracken, director of the Office of Space Science and Applications of the Commonwealth Scientific and Industrial Organization, Western countries have been reluctant to use Soviet vehicles because of concern over transfer of sensitive technological information. "The Russians are pragmatic", he said.

"They know that, regarding latitude and climate, our facility will be superior to the one at Cape Canaveral. They also know that they will not break through the US embargo on information arising from American technology entering the USSR. We are offering them a commercial alternative."

Tania Ewing ozone layer, deforestation, desertification, pollution, acid rain and the 'greenhouse effect'. New projects will be in operation by the early 1990s, based on what the conference's working group on 'space-based ISY mission components', a "fantastic array" of orbiting instruments.

The plan is that national space agencies should supply full inventories of scheduled projects for entry into a global compendium. One of the projects likely to figure prominently is NASA's Upper Atmosphere Research Satellite (UARS), to be launched in the early $1990 \mathrm{~s}$, whose chief purpose is to determine the extent and durability of the ozone layer. Instrumentation will be provided by the United States, Britain, Canada and France, with international data analysis.

Another project is the Japanese Advanced Earth Observing Satellite which may, among other instruments, carry a 'scatterometer' to measure seasurface wind velocity. The ESA's remotesensing satellite mission, ERS-1, and a joint French-US TOPEX/Poseidon pro- gramme to be launched aboard an Ariane rocket, will both provide a wide array of new data on ocean circulation patterns and variability. Other projects are planned by the Soviet Union and India.

Despite the large number of scheduled launches of instruments that could be included in ISY, the consensus at the meeting is that there is very little time to organize a truly integrated international programme by 1992 . Most participants agreed that the more important goal is to establish the foundation for a consistent long-term strategy.

One obstacle to an integrated programme, that of organizing the data, was addressed by several working groups. The full extent of the database was likened by some to "literally hundreds of times that of the US Library of Congress", which is why one working group proposed dividing reference databases into units concerned with different topics such as vegetation patterns, soil moisture, permafrost, sea level, ocean colour, sea surface temperature and stratospheric chemistry.

One clear theme is that, thanks to vast new stores of data from space, the Earth environment must increasingly be seen as a system in which no single variable can be understood in isolation. Seth Shulman

\section{AIDS brochure launched despite doubts}

\section{Washington}

ThE US Public Health Service last week unveiled its educational brochure on AIDS, to be mailed to every household in the United States by the end of June. Over 107 million copies of the eight-page leaflet entitled Understanding AIDS will be mailed, at a cost of $\$ 17$ million.

The brochure contains a frank discussion of the modes of AIDS transmission and identifies who should be tested for anti-

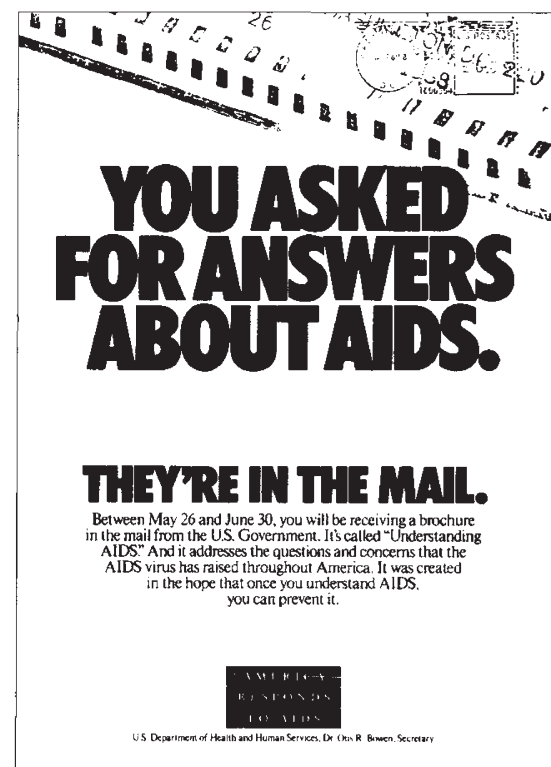

The poster announcing Koop's message. bodies to human immunodeficiency virus (HIV), the virus causing AIDS. It gives equal space to discussions of condom use, abstinence from drug use and care in selection of sexual partners to prevent contact with the virus.

The long-awaited brochure should have been mailed last autumn, but was withheld until a compromise could be reached between President Ronald Reagan's approach of instructing people to "just say no" and Surgeon General C. Everett Koop's advice that they should use condoms. The $\$ 20$ million set aside for the production and mailing of the brochure in last year's budget was absorbed into an expansion of the national AIDS hotline and the distribution of a less specific brochure to non-profit organizations and state and local health departments (see Nature 331, $470 ; 1988$ ).

The effect of the brochure on the public's knowledge of AIDS will be gauged through responses to the current National Health Interview Survey on a multitude of health topics administered by the National Center for Health Statistics. Questions about AIDS were added to the randomly administered survey starting in August last year. The survey will also attempt to assess the effect of increased knowledge about AIDS on behaviour: questions about sexual practices and drug use are expected to be added this summer. 